原著

\title{
体外循環下超低体温を用いた血栓化巨大脳動脈瘤の クリッピング術
}

\author{
大滝 雅文, 上出 廷治, 野中 雅 \\ 田邊 純嘉, 端 和夫
}

\section{Direct Clipping of Giant Partially Thrombosed Basilar Artery Aneurysms Using Cardiopulmonary Bypass with Deep Hypothermia}

Masafumi Ohtaki, M.D., Teiji Uede, M.D., Tadashi Nonaka, M.D., Sumiyoshi TANaBe, M.D., and Kazuo HaSHI, M.D.

Department of Neurosurgery, Sapporo Medical University School of Medicine, Sapporo, Japan

Summary: Direct clipping of giant thrombosed basilar artery (BA) aneurysms continues to pose a formidable challenge in spite of the widespread use of skull base surgery technique. Recently, we employed deep hypothermic circulatory arrest for 2 cases of such complex BA aneurysms with the aid of cardiac surgeons and neuroanesthesiologists.

Canulation for cardiopulmonary bypass was performed centrally through the atrium in Case 1 (open chest technique) and peripherally through the femoral vein in Case 2 (closed chest technique). In both cases, giant thrombosed BA aneurysms were directly clipped without any new neurological deficits. The open chest method has several advantages such as rapid response to cardiac over-distension and ventricular fibrillation, and reduction of cooling and rewarming times. However, increased blood loss and post-operative pericardial and pleural effusion resulting from central canulation may occur. In this context, the simple closed chest technique is preferable unless the patient has severe aortic valve disease and significant organic dysfunction.

Heparin-coated equipment can be utilized to prevent serious hemorrhagic complications due to clotting defect. During circulatory arrest, the blood is not drained from the patient through the cardiopulmonary bypass because of the risk of air embolism and migration of intraluminal thrombus. Low-flow bypass is also preferred as an alternative to complete circulatory arrest for protection of the brain and other organs, and for identification of perforators around the aneurysm. Deep hypothermia with the option of circulatory arrest can be indispensable to the safe management of complex basilar artery aneurysms.

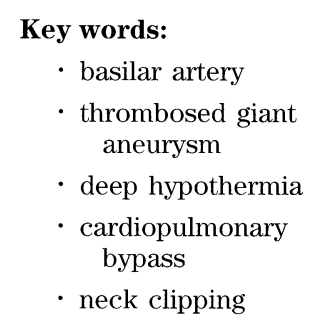

Surg Cereb Stroke (Jpn) 26: 181-188, 1998

札幌医科大学 脳神経外科(受稿日 1997.8.29) 〔連絡先： ₹060-8543 札幌市中央区南 1 条西 16 丁目 札幌医科大学 脳神経外科 大滰 雅文〕〔Mailing address: Masafumi Oнtaki, M.D., Department of Neurosurgery, Sapporo Medical University School of Medicine, South-1, West-16, Chuo-ku, Sapporo 060-8543, Japan] 


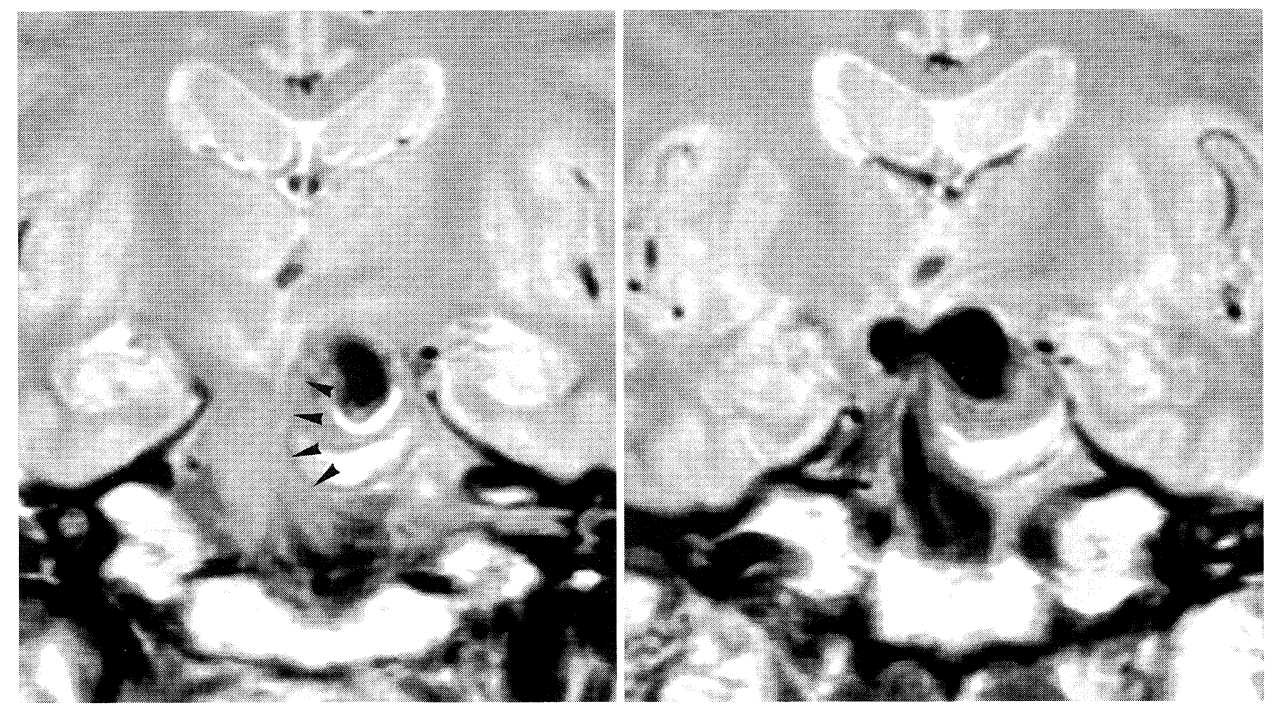

Fig. 1 MRI proton coronal images $(\mathbf{A}, \mathbf{B})$ showing dumbbell-shaped upper basilar artery aneurysms, one of which is largely thrombosed and causes brain stem distortion (arrowhead).

A B

\section{はじめに}

巨大脳動脈瘤が椎骨脳底動脈にある場合，頭蓋底外科の 手術手技を応用し working spaceの拡大を図ることが必須 と考えられるが, 最深部の狭い術野で長時間多数の temporary clip 使用しながら，穿通枝を温存しクリッピン グを完了することはきわめて困難なことである。このよう な後頭蓋窩の complex aneurysmのクリッピング術を超低 体温循環停止下に行うことは，すでに北米を中心に発展し その有用性が認められているが11)13)15１6），本邦において は少数の成功例が報告されているにすぎない ${ }^{5) 8) 9) 11) . ~}$

最近心臟血管外科医ならびに麻酔科医の協力を得て, 中 心温 $20^{\circ} \mathrm{C}$ の体外循環下超低体温でクリッピングを行った 2 例の血栓化巨大脳底動脈瘤の直達術を報告する。

\section{体外循環下超低体温の手技と症例呈示}

\section{1. 術前評価と準備}

心機能の術前評価が最も重要であり, 最低限 12 誘導お よび負荷心電図, 心エコー検査が必要となる. なかでも心 エコーによる大動脈弁の機能評価は必須で, 閉鎖不全があ れば後述する open chest法を選択しなければならない12) 14）。また虚血性心疾患の既往があれば，術前に冠動脈力 テーテル検查を行っておく.

超低体温それ自体に起因する出血傾向, 免疫能低下, 肺 毛細血管 permeabilityの立進や肝腎機能の低下を考え, 凝固・線溶系, 肺・肝 - 腎機能, 免疫能および感染症の有 無など内科的検索を詳細に行っておく.
超低体温自体や全身のへパリン化による出血傾向や開胸 術 (open chest 法)に伴う失血に対してすみやかに対応で きるよう，十分な輸血用赤血球，血小板血や凍結人血漿を 準備しておく．また術前までに少なくとも $200 \mathrm{ml}$ 以上の 貯血を行い，それを手術当日に入れ換えることで自己血生 血を生成するか，あるいは生血の供血者数名を確保してお く必要がある.

\section{2. 体外循環下超低体温を用いた脳動脈瘤手術}

体外循環による超低体温循環停止法には, open chest 法と closed chest法がある. 今回の 2 症例では, 患者の術 前評価に応じてそれぞれの方法を採用したので，手術手技 とともにその実際について詳しく述べる.

\section{〈症例 1〉 52 歳, 女性：open chest法.}

左動眼神経麻痺による複視で発症した血栓化巨大脳底動 脈瘤の症例である．動脈瘤は脳底動脈の先端部で二コブ状 となり, 近接する左大脳脚から橋上部は血栓化部分により 大きく変形し (Fig. 1), その頸部はbroad で左後大脳動脈 と左上小脳動脈との間にあることが3-dimensional CT angiography (3D-CTA)で理解された (Fig. 2).

手術は動脈瘤とその parent arteryである脳底動脈中枢 側を同一術野で確保できるよう, 後床突起から斜台上縁外 側の骨削除を追加した left transcavernous approachで行 うことにした。しかし通常の体外循環装置を使用する場 合，全身のヘパリン化は必須であり，海綿静脈洞を開放し た際の出血のコントロールがきわめて困難になると予測さ れた。このため二期的手術を計画し，初回手術は常温麻酔 

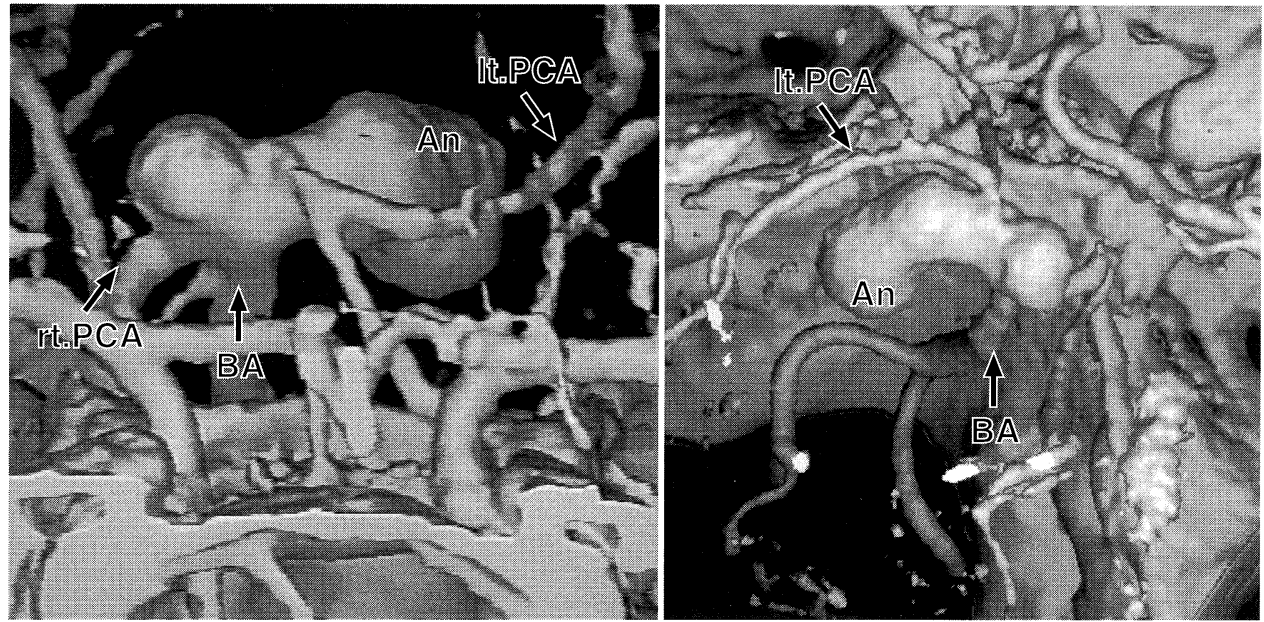

Fig. 2 Three-dimentional CT angiography (anterosuperior: A and left posterosuperior: B views) demonstrating the broad neck of the thrombosed basilar artery (BA) aneurysm (An) located between the left posterior cerebral artery (PCA) and the left superior cerebellar artery.

A $\mathbf{B}$
下で動脈瘤と脳底動脈中枢側を露出するに留めた。特に開 放した海綿静脈洞からの出血はOxycel ${ }^{\circledR}$ を用いて丹念に止 血した。

2 週間後の体外循環下超低体温による直達術では, orbitozygomatic osteotomyを追加した。麻酔導入時より thiamylal $\mathrm{Na} 5-10 \mathrm{mg} / \mathrm{kg} / \mathrm{min}$ を持続投与し，体外循環開 始前に脳波上は burst-suppressionに到達していた。顕微 鏡が導入された時点より体表面冷却を開始し，脳底動脈瘤 を再び露出したのち，心臓血管外科チームにより胸骨正中 切開が行われた.ヘパリンの静注後，右心房に切開を加え 下大静脈に向かって先端 $36 \mathrm{~F}$ の静脈脱血管を挿入した. ついで送血用の 19F のチューブを大腿動脈から総腸骨動 脈へ扱入し，体外循環装置を介して毎分 2.61 の脱血量が 確保された (Fig. 3)。体外循環開始後はへパリンの追加投 与により活性凝固時間 $(\mathrm{ACT})$ を 350 秒以上に保ち，回路 内の血栓化を防いだ。冷却開始 45 分後には，心停止を経 て，目標鼓膜温 $20^{\circ} \mathrm{C}$ に到達していた。この時点より動脈 瘤に切開を加え瘤内血栓の摘出を進めたが，その間体外循 環装置を停止することなく，定常流で平均動脈圧 50-60 mmHgの体循環を維持していた。このため動脈瘤よ り出血があり数回の脳底動脈中枢側の一時血流遮断を併用 しながら，周囲の穿通枝と動眼神経を剝離温存してクリ ッピングを完了した。

復温後, 中心温が $30{ }^{\circ} \mathrm{C}$ 付近に達した時点より心拍は自 然再開し sinus rhythmとなった。その間顕微鏡下に，ク リッピングが完全で体血圧が上昇しても動脈瘤から出血が 起こらないことを確認した。持続モニタリングを行ってい たSEPの N20の peak は冷却とともに徐々に遅延し, 中心

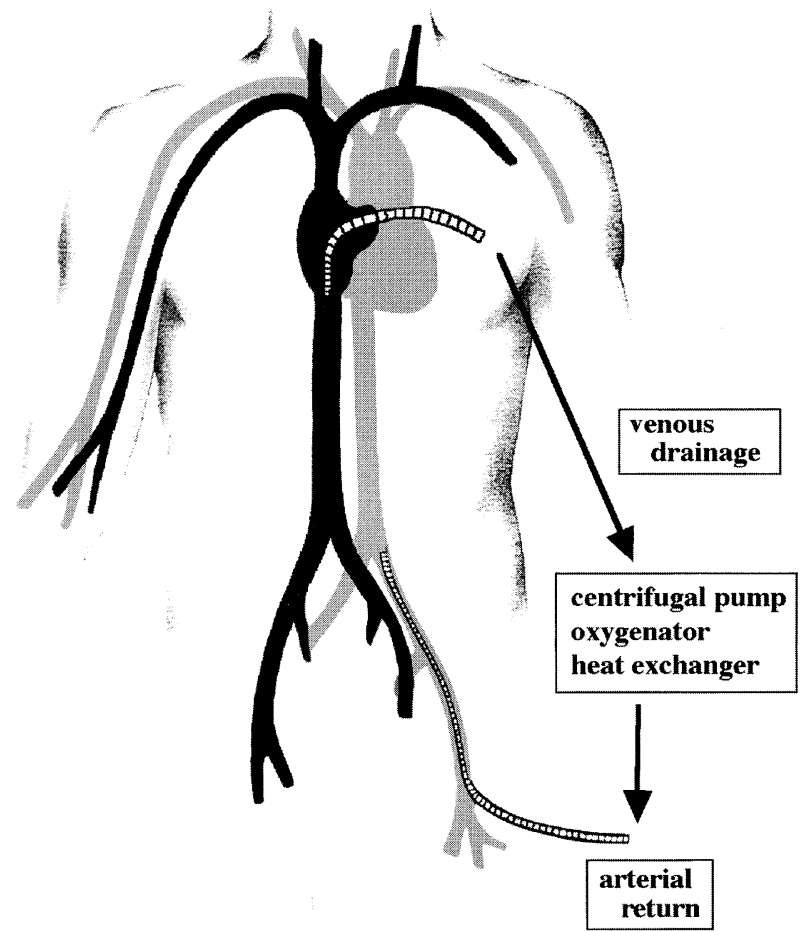

Fig. 3 Schematic presentation of the central canulation for extracorporeal circulation (open chest technique). The right atrium and the femoral artery are directly canulated for venous drainage and arterial return, respectively.

温 $25^{\circ} \mathrm{C}$ 以下で不明暸となったが，復温とともにコントロ ールまで回復した。手術中の体外循環時間は 122 分，心停 止時間は 52 分, 3 回行った脳底動脈の一時血流遮断は計 
Table 1 Details of extracorporeal perfusion during deep hypothermia

\begin{tabular}{lccccccc}
\hline & Procedure & $\begin{array}{c}\text { Bypass } \\
(\mathrm{min})\end{array}$ & $\begin{array}{c}\text { Cooling } \\
(\mathrm{min})\end{array}$ & $\begin{array}{c}\text { Cardiac arrest } \\
(\mathrm{min})\end{array}$ & $\begin{array}{c}\text { Circulatory } \\
\text { arrest }(\mathrm{min})\end{array}$ & $\begin{array}{c}\text { Bypass flow } \\
(1 / \mathrm{min})\end{array}$ & $\begin{array}{c}\text { Core temp. } \\
\left({ }^{\circ} \mathrm{C}\right)\end{array}$ \\
\hline Case 1 & open chest & 122 & 45 & 52 & low flow & 2.6 & 20 \\
Case 2 & closed chest & 125 & 48 & 28 & 19 & 1.6 & 20 \\
\hline
\end{tabular}
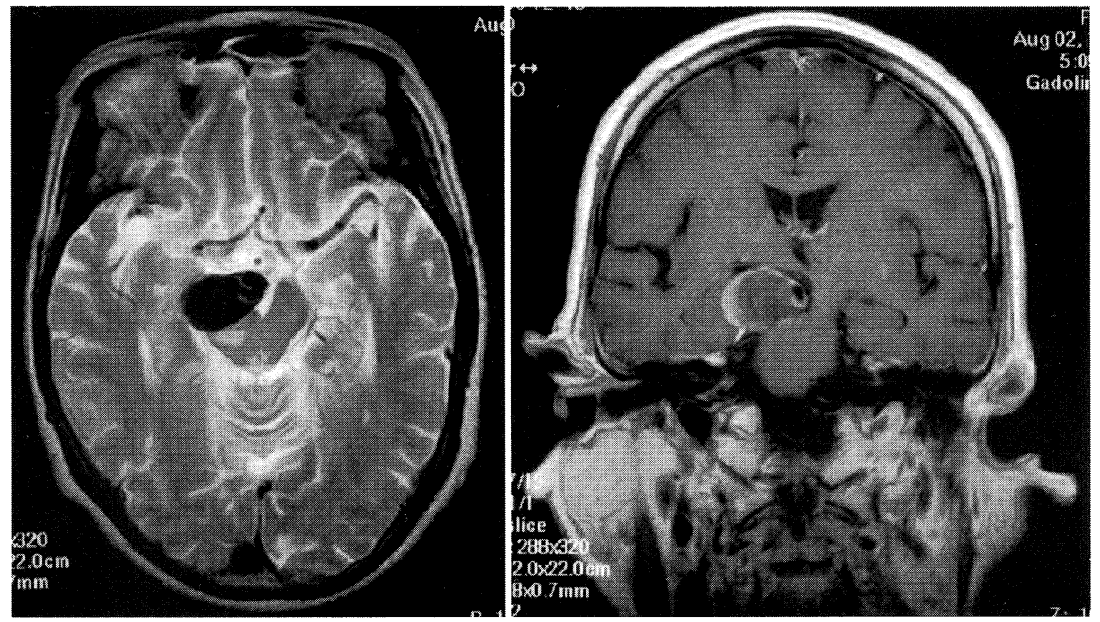

Fig. 4 MRI T2-weighted axial $(\mathbf{A})$ and T1-weighted coronal $(\mathbf{B})$ images showing a largely thrombosed basilar artery aneurysm. A small high signal intensity lesion on the T2-weighted image is observed in the right distorted cerebral peduncle adjacent to the aneurysm.

A $\mid$ B

14 分 18 秒であった (Table 1). 体外循環終了後プロタミン でヘパリンの中和を行い ACT は 137 秒 (コントロール值は 130 秒)にまで短縮したが, 海綿静脈洞あるいは近傍の硬 膜外腔より漏出性出血が持続した。このため血小板血 20 単位, 凍結人血漿 15 単位, さらに供血者からの生血 $600 \mathrm{ml}$ の輸血を要して, ようやく出血がコントロールさ れるようになった，術中の出血量は，その大半が開胸によ って失われたものであるが, 約 $3000 \mathrm{ml}$ にも達していた。

〈症例 2〉68歳, 女性： closed chest法.

右動眼神経麻痺と左片麻疩を呈した巨大血栓化脳底動脈 瘤の症例である.MRIでは動脈瘤の大部分が血栓化し， 強く圧排された右大脳脚の一部に高輝度領域が認められた (Fig. 4). またDSA，3-D CTA で脳底動脈先端部は高位 にあり，動脈瘤頸部は右後大脳動脈の中枢側にあると判断 した(Fig. 5).

クリッピング術は脳底動脈先端部まで十分到達できるよ う right orbitozygomatic approachを用いることにした。 症例 1 と同様に脳波と SEP のモニタリング下に thiamylal $\mathrm{Na}$ の持続投与を行い，まず常温下で脳底動脈瘤を露出し た Fig. 6). 次に心臓血管外科医により $25 \mathrm{~F}$ の静脈脱血管
が右大腿静脈より右心房まで，そして $19 \mathrm{~F}$ の送血管が左 大腿動脈を介して挿入された (Fig. 7). 体外循環開始後毎 分 1.61 の循環血液量が確保され, 鼓膜温 $25{ }^{\circ} \mathrm{C}$ 前後で心室 細動となり, 目標温 $20^{\circ} \mathrm{C}$ 到達し心停止となった。冷却 に要した時間は 48 分であり，非開胸による有意な延長は なかった。顕微鏡下に脳幹への減圧を図るため瘤内血栓の 摘出を開始したが, 動脈瘤より出血をきたした時点で体外 循環装置を切り完全循環停止とした。 その後も出血が持続 したが，サクションにより十分コントロールされるため, 静脈側チューブの開放による脱血は行わなかった. 脳底動 脈背側の穿通枝と動眼神経を剥離しクリッピングを完了 した(Fig. 6).

この症例ではへパリンの全身投与量を最小限とするため に，回路内のチューブのみをへパリンコーティングした体 外循環装置 (percutaneous cardiopulmonary support system: PCPS) を利用した. 大腿動静脈へカニュレーション を行う前にへパリン 3,000 単位を静注したが, その後へパ リンを追加投与することなく ACT は 200 秒前後で経過し た. 復温後も血中ヘパリン濃度をモニターしたが, プロタ ミンによる中和を行わずとも体外循環終了時の ACT は 


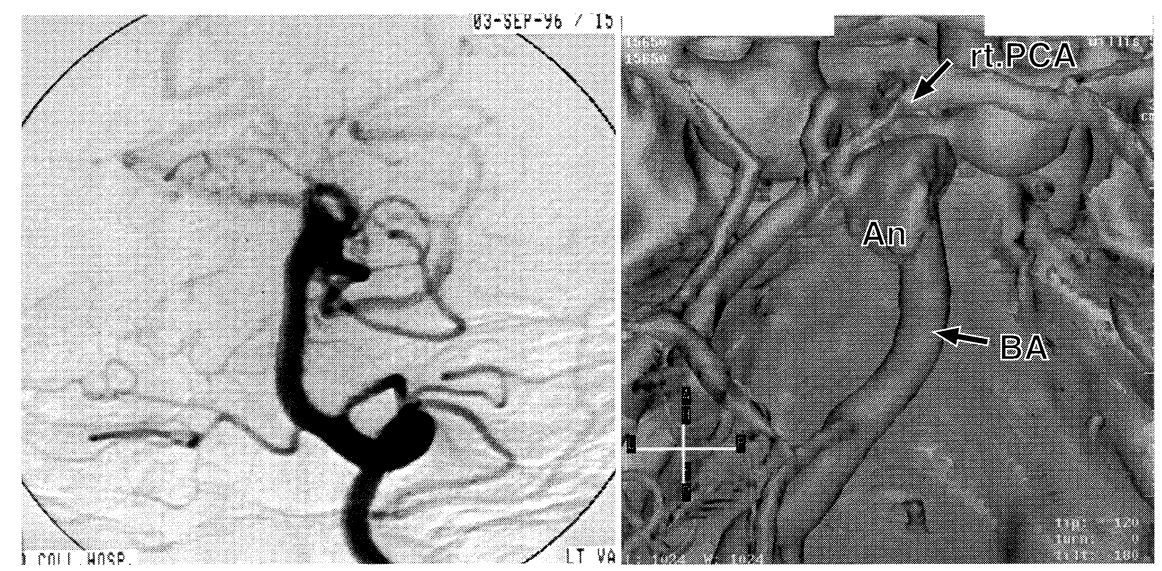

Fig. 5 Vertebral angiography (anteroposterior projection, $\mathbf{A}$ ) and 3-dimentional CT angiography (posterosuperior view, B) demonstrating the neck of the thrombosed basilar artery $(\mathrm{BA})$ aneurysm $(\mathrm{An})$ located higher and proximal to the right posterior cerebral artery (PCA).
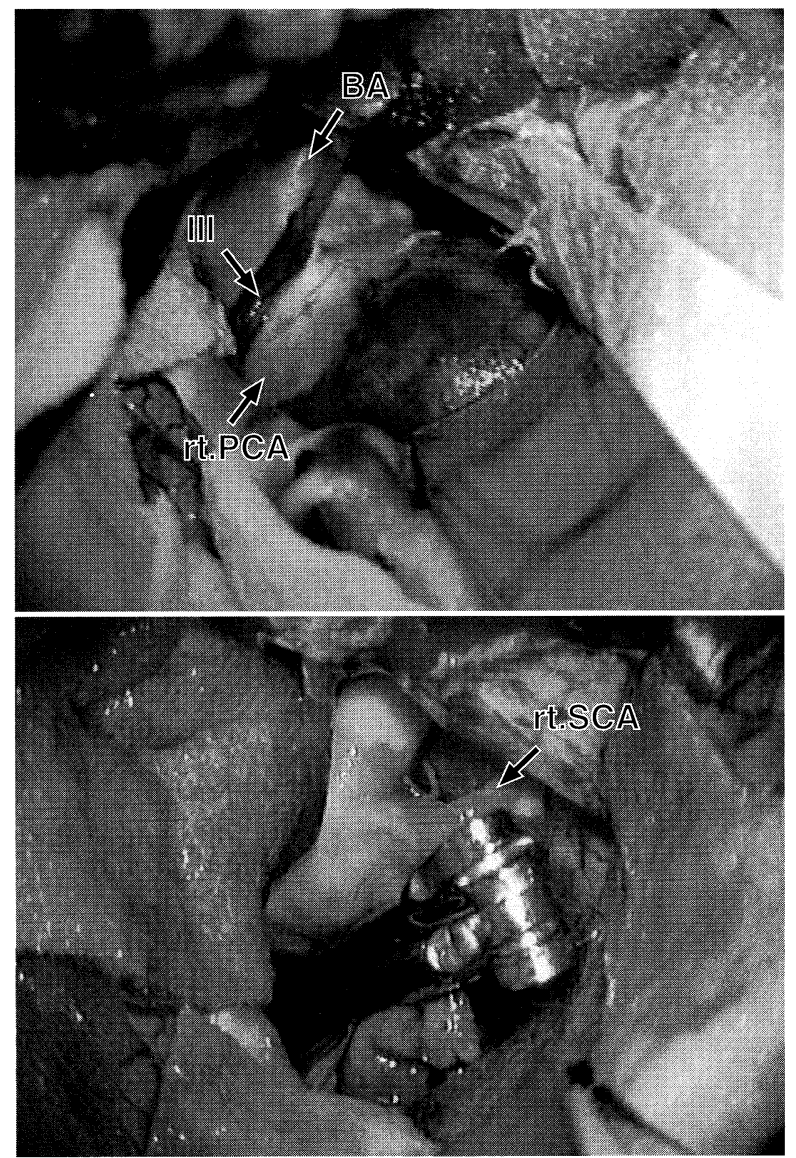

Fig. 6 Intraoperative views. A: The broad neck of the thrombosed giant basilar artery (BA) aneurysm is sufficiently exposed through the right orbitozygomatic approach. III: oculomotor nerve, PCA: posterior cere-

bral artery. B: Two long straight clips are applied to the aneurysmal neck. SCA: superior cerebellar artery.

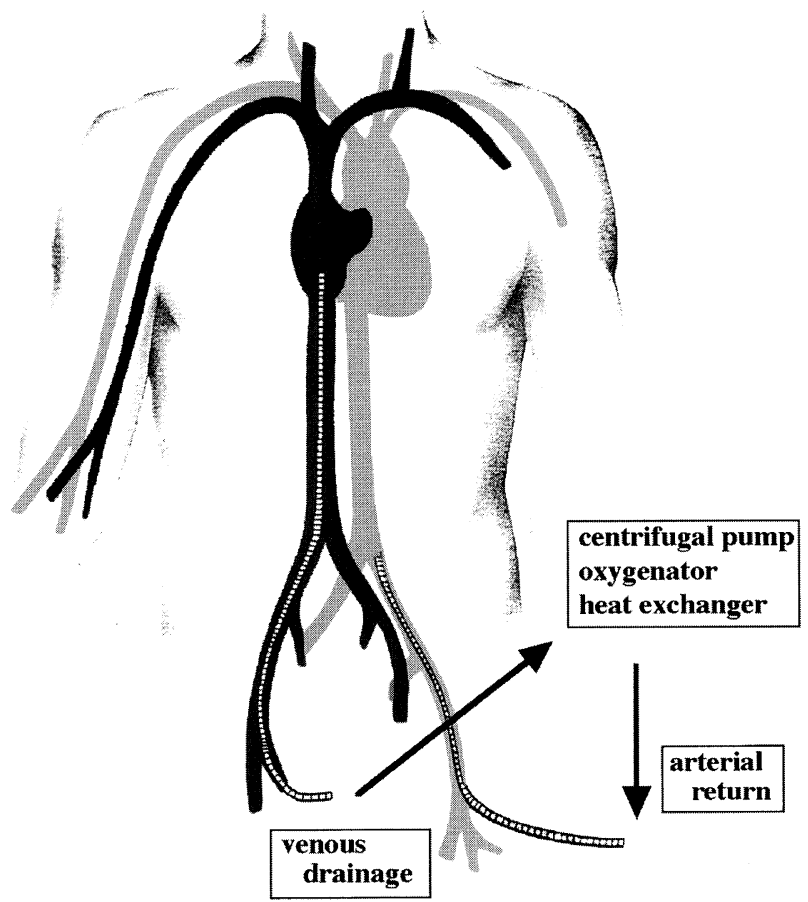

Fig. 7 Schematic presentation of the femoral canulation for extracorporeal circulation (closed chest technique). The femoral vein is canulated and the venous canula is advanced into the right atrium for improved venous drainage. 
133 秒(コントロール值は 86 秒)となった。その結果，症 例 1 と比較し明らかに止血操作が容易となり, 術中の総出 血量も $600 \mathrm{ml}$ に抑えられた。また止血効果を上げるため の輸血も自己血生血 $200 \mathrm{ml}$ と凍結人血漿 4 単位のみであ った。手術中の体外循環時間は 125 分，心停止時間は 28 分，完全循環停止は 19 分間であった(Table 1).

\section{3. 術後管理と症例の転帰}

術後は十分に覚醒するまで人工呼吸器下に管理された。 症例 2 では術翌日に気管内挿管を抜去することができた が, 症例 1 では開胸術に起因する心囊水や胸水の貯留があ り,術後 3 日目まで呼吸管理が必要であった。また大量の 利尿剂を投与し third spaceからの水分除去を行ったが, その一方で脳循環に悪影響を与えないよう循環血液量は十 分に確保するよう努めた。

CTで出血や脳浮腫のないことを確認したのち, 脳底動 脈の血栓性閉塞や塞栓症を予防するためメシル酸ナファモ スタットを術直後より持続投与した。またアスピリンは術 翌日より投与を開始した。これは大腿静脈の血检性静脈 炎，肺梗塞などを予防するためにも有用と考えられる ${ }^{16)}$. 2 症例とも動眼神経麻痺の増悪を認めたが，重篤な合併症 や新たな神経脱落症状を残すことなく, 症例 1 は術後 2 カ 月半で自宅退院し, 症例 2 は術後 5 カ月でリハビリテーシ ヨンを目的として他医に転院した。

\section{考察}

\section{1. 超低体温循環停止法とその適応}

脳動脈瘤手術に microsurgery techniqueが導入され， その手術成績が飛躍的に向上した 1970 年代以降，超低体 温循環停止法は高頻度の術後合併症のために通常の脳動脈 瘤手術には用いられなくなった。しかしその後の心臟血管 外科の手術手技や麻醉管理の向上，さらに人工心肺装置な どの technology の進歩により，後頭蓋窩などの complex aneurysm の直達術を中心に新たな展開をみせている ${ }^{1)-4)}$ 7) 12) -18).この方法は通常の顕微鏡下手技では直達術がき わめて困難と考えられる脳動脈瘤に適応されるが, Ausman らは脳深部の巨大動脈瘤でその流入動脈の確保が 困難なもの, 体部や頸部の剥離操作に長時間の temporary clipping を要し, 特に穿通枝領域の脳虚血が危惧さ れるもの，巨大血栓化動脈溜のように瘤の減圧を加えなけ れば周囲脳や脳神経との剝離操作で障害を残す危険性が 高いものをあげている ${ }^{1)}$. したがって最近 10 年間の報告 をみると，手術症例の多くが大きな椎骨脳底動脈瘤である が，ウィリス輪前半部でも頸部の硬化性変化の強い血栓化 巨大動脈瘤や血行再建に長時間を要する症例にも本法が適 用されている ${ }^{12)}{ }^{13) 16)}$ ，その手術成績はいずれの報告でも
脳神経外科医に希望を与えるものであり, 現在北米では巨 大脳動脈瘤への対処法として定着した感がある. しかしそ の一方で本法の過大適応への懸念もある. Solomon らは 1991 年以降に経験した 31 症例中, 超低体温循環停止法に 起因する 3 例の死亡例を経験し，この方法は他のいかなる 手技によっても安全なクリッピングが行えないと判断され た巨大脳動脈瘤の直達術に限定されるべきであると述べて いる ${ }^{14)}$.

\section{2. 体外循環法の比較：open chest 法と closed chest 法} 超低体温を得るための体外循環とそのカニュレーション には, 症例呈示で述べたように開胸による脱血法 (open chest 法) と末梢の大腿静脈を介する方法 (closed chest法) とがある。

open chest法では必要かつ十分なサイズのカニューレ を右心房に挿入し脱血量をコントロールすることで，早急 な冷却と加温, そして安定した中心温管理が可能となる。 また循環停止により肺静脈の血液が左心室に流れ込んで生 ずる異常拡張や心筋障害にすみやかに対応できることと， 冷却時に起こる不整脈に対して体循環を確保できるといっ た利点があげられる ${ }^{47)}$. その一方で開胸術の侵襲性と出 血量の増加, さらに開胸に起因する心囊水や胸水の貯溜, 縦隔感染症のリスクなど, 術後管理にいくつかの問題点を 残している。これに対して closed chest法は侵襲性が少な く，頭部の術野から離れ十分なスペースでカニュレーショ ンが行えるなどの利点がある. しかし患者の体格が小さい 場合には必要な太さの脱血管を挿入できない，また挿入で きても脱血管が右心房に至らず十分な脱血量を確保できな い場合冷却時間の延長や臟器血流不全をきたすこと, さら に左心室に生ずる異常拡張への対応困難などが問題となる 14)。また術後の大腿静脈などの深部血栓症が 10-27\%にみ られ，肺梗塞をきたした症例も報告されている ${ }^{2) 13)}$.

症例 1 は一側の腎臓が摘出された患者であり, 腎血流低 下のリスクが少ないopen chest法を採用した。しかし多 大な失血量や胸水貯留の持続など術後管理に問題を残した

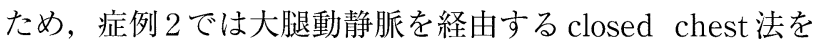
用いた。これらの経験から， Solomon らが勧めるように大 動脈弁不全や大動脈疾患, あるいは肝臓などの臟器不全を 合併していなければ closed chest法を選択するのがよいと 考えている ${ }^{14)}$. しかし挿入した静脈カニューレからの脱 血量が予測值の $80 \%$ に達しないときには, 中心静脈への 直接カニュレーションが必須となり, closed chest法であ っても必ず胸部の術野は確保しておかなければならない 14) 16) 


\section{3. 超低体温の全身への影響とその対処}

非生理的な $20{ }^{\circ} \mathrm{C}$ 以下の超低体温下では全身への影響も 大きく, 血液凝固系の異常による出血傾向, 酸素消費の低 下によるアルカローシス, 肝抢よび腎機能の低下による薬 物代謝の変化, グルコースの消費抑制による高血糖, 脳血 管を含めた末梢血管抵抗の増大と血液粘度の立進による臓 器血流量の低下などがあげられ，術中より適切な対応が必 要となる. Spetzler はこのような超低体温自体の潜在的な 危険性から, 手術を安全に進めるために以下の五つのキー ポイントを提示している：1. 低体温の深さ，2．循環停 止の長さ，3. バルビッレートの静脈内持続投与, 4. 術中 の止血操作，5. 緩徐な復温である ${ }^{15)}$.

ヒトに拀いても $30^{\circ} \mathrm{C}$ 以下の低体温では, $1{ }^{\circ} \mathrm{C}$ 体温が低 下するとともに脳酸素消費量が $7 \%$ 減少し, 脳虚血の critical timeは低体温により延長するというのは周知のことで ある。臨床でも成人の脳神経外科手術では $15-18^{\circ} \mathrm{C}$ の超低 体温下で 45-60 分間まで, また小児の心臟外科手術では 18-20 ${ }^{\circ} \mathrm{C}$ の超低体温下で $60-90$ 分間までの完全循環停止は 安全とされている ${ }^{16)}$ 。しかし超低体温それ自体の悪影響 を考えると循環停止時間の短縮を図ることはいうまでもな く，そのためには循環停止前の常温下で脳動脈瘤を可及的 に剝離しておくこと, 低体温導入後はすみやかな操作で クリッピングを目指すことである。

バルビッレートの静脈内投与は一過性全脳虚血に対して 脳保護作用を有することが実験的にも証明されており，当 然超低体温法と併用すれば循環停止時間の延長が図れるの ではという期待が生まれてくる ${ }^{15)}$ 。体外循環装置を用い た心臟外科手術患者に扔いて, バルビッレートの持続投与 を受け脳波上 burst-suppression が得られた患者で術後の 神経精神症状の回復が有意に優っていたという報告がある 10).

\section{4. 血液凝固異常と PCPS の有用性}

過去には低体温による血液凝固異常に対する認識不足か ら, 術野への漏出性出血など多くの出血合併症により低体 温手術の成績はきわめて悲惨なものであった ${ }^{6)}$. 出血傾向 の要因として, 低体温自体による血小板減少と機能異常, 凝固反応の遅延，血液希勫による凝固因子の減少，さらに 体外循環装置を使用するための全身へパリン化などが考え られる。したがって体外循環から離脱したのちに，プロ夕 ミンによるへパリンの中和，血小板輸血や凝固因子の補充 を行うが, 術中は出血合併症を回避するための注意深い手 術操作が要求される，たとえば全身のへパリン化や低体温 の導入前に，展開した術野での完全な止血を確認しておく こと，脳べラの掛ける位置を頻回に移動させることなどで

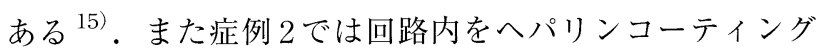

した心肺装置 (PCPS) を利用したが，これによりへパリ ンの全身投与量を減らし，体外循環中も ACT 200 秒前 後に設定することできた，その結果，術野への漏出性出血 は明らかに少なく復温後の止血操作も容易となった．この 装置はすでに胸部外科や救命救急の臨床において心肺停止 例の蘇生手段や経皮的心肺補助として応用され，出血合併 症あるいは血栓塞栓症も少なく, 今後超低体温下での脳神 経外科手術にも広く用いられようになると思われる ${ }^{7) 16) . ~}$

\section{5. 術中の体外循環の管理}

症例 1 では腎血流量を保持するために, 心停止後も体外 循環装置を用いて定常流を維持した。脳組織代謝の面から も完全循環停止と比較し低流量体外循環が脳保護的である ことが実験的に示され， $20^{\circ} \mathrm{C}$ 以下の低体温でも $11 / \mathrm{min} の$ 低流量バイパスを推奖する報告もある ${ }^{3)}$ 17)。また完全循 環停止下では穿通枝が虚脱し, くも膜の索状構造との識別 が困難になると指摘され ${ }^{1)}$, 穿通枝損傷を回避するために も低圧定常流バイパスは有用と考えられる。一方これまで に報告された超低体温循環停止法のプロトコールをみる と,多くの症例で体外循環停止後に無血術野を得るために, 心肺装置の静脈側から脱血を行っている ${ }^{1) 2) 16) 18)}$. しかし 脱血により脳血管を過度に虚脱させてしまうと, 術中すで に動脈瘤を切開している場合には空気塞栓の危険が，また クリッピング後循環が再開されても穿通枝領域の no reflow phenomenonによる虚血の持続が危惧される ${ }^{14)}$. し

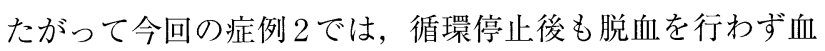
管内血液の自然流出を図り, 瘤内血栓摘出時の遊離血栓に よる末梢動脈塞栓や空気塞栓を防ぐよう努めた.

\section{結 語}

超低体温循環停止法は後頭蓋窩などの complex aneurysmに対してきわめて有効な手段であるが，その一方 complex procedureでもあり超低体温自体による合併症の リスクも高い。したがって開胸あるいは非開胸による体外 循環法の利点と問題点，また患者の転帰を大きく左右する 出血合併症を回避するための術中操作の要点, ヘパリン・ コーティング回路の有用性などについて術前より十分理解 しておく必要がある.

稿を終えるにあたり，体外循環下超低体温の導入と管理 にご尽力いただいた札棍医科大学医学部胸部外科ならびに 麻酔科の諸先生に深謝いたします。

\section{文献}

1) Ausman JI, Malik GM, Tomecek FJ, et al: Hypothermic circulatory arrest and the management of giant and large 
cerebral aneurysms. Surg Neurol 40: 289-298, 1993

2) Baumgartner WA, Silverberg GD, Ream AK, et al: Reappraisal of cardiopulmonary bypass with deep hypothermia and circulatory arrest for complex neurosurgical operations. Surgery 94: 242-249, 1983

3) Chaney MA: Profound hypothermic circulatory arrest for noncardiac surgery via the closed-chest technique. Anesth Analg 76: 892-897, 1993

4) Chyatte D, Elefteriades J, Kim B: Profound hypothermia and circulatory arrest for aneurysm surgery. J Neurosurg 70: 489-491, 1989

5）伊達 勲, 衣笠和孜, 大本堯史：超低体温による脳動脈瘤 手術. Clin Neurosci 13: 370-371, 1995

6) Drake CG, Barr HWK, Coles JC, et al: The use of extracorporeal and profound hypothermia in the treatment of ruptured intracranial aneurysm. J Neurosurg 21: 575-581, 1964

7) Jolin A, Eden E, Borggren $\mathrm{H}$, et al: Management of a giant intracranial aneurysm using surface-heparinized extracorporeal circulation and controlled deep hypothermic low flow perfusion. A case report. Acta Anesthesiol Scand 37: 756-760, 1993

8）加藤庸子, 佐野公俊, 山口幸子, ほか：空形成を伴った椎 骨動脈合流部の large 動脈瘤の治療例：低体温, 体外循環下 にクリッピングしえた 2 症例. 脳卒中の外科 24: 115-121， 1996

9）久山秀幸, 長尾省吾, 猪俣園江, ほか：超低体温循環停止 により手術を行った右後大脳動脈 (P2) 血栓化動脈瘤の1例. 脳卒中の外科 23: 93-98, 1995

10) Nussmeier NA, Arlund C, Slogoff S: Neuropsychiatric com- plications after cardiopulmonary bypass: Cerebral protection by a barbiturate. Anesthesiology 64: 165-170, 1986

11）大滝雅文, 上出廷治, 越知さと子, ほか：Transcavernous approach による巨大脳底動脈瘤のクリッピング．脳卒中の 外科 25: 24-32, 1997

12) Pacult A, Gratzick G, Voegele D, et al: Surgical clipping of difficult intracranial aneurysms using deep hypothermia and total circulatory arrest. South Med J 86: 898-902, 1993

13) Solomon RA, Smith CR, Raps E, et al: Deep hypothermic circulatory arrest for the management of complex anterior and posterior circulation aneurysms. Neurosurgery 29: $732-738,1991$

14) Solomon RA: Principles of aneurysm surgery: Cerebral ischemic protection, hypothermia, and circulatory arrest. Clin Neurosurg 41: 351-363, 1994

15) Spetzler RF, Hadley MN, Rigamonti D, et al: Aneurysms of the basilar artery treated with circulatory arrest, hypothermia, and barbiturate cerebral protection. J Neurosurg 68: 868-879, 1988

16) Steinberg GK, Grant G, Yoon EJ: Intraoperative Neuroprotection, Williams \& Wilkins, Baltimore, 1996, pp 65-84

17) Swain JA, McDonald TJ Jr, Griffith PK, et al: Low-flow hypothermic cardiopulmonary bypass protects the brain. J Thorac Cardiovasc Surg 102: 76-84, 1991

18) Williams MD, Rainer WG, Fieger HG, et al: Cardiopulmonary bypass, profound hypothermia, and circulatory arrest for neurosurgery. Ann Thorac Surg 52: 1069-1075, 1991 